\title{
Correlation of Medical Treatment for Wound Infection with Isolated Bacteria and Antibiotics Sensitivity Profile in Baqubah Teaching Hospital \\ Ammar A Mohammed(MD,CABM $)^{1}$, Mohamed A Al-karkhi $(\mathrm{PhD})^{2}$,Firas A Al- Taie(MSc) ${ }^{3}$ and Imad Ahmed Lateef (MD,CABM $)^{4}$ \\ Abstract
}

Background: Despite of the advancement in surgery, surgical techniques and use of antibiotics prophylaxis, postoperative infections remain the commonest postoperative complications and one of the most frequently encountered nosocomial infections worldwide. These infections lead to increase morbidity with the attendant increase in cost of therapy.

Objective: To evaluate the antimicrobial susceptibility pattern among the most common bacteria associated with postoperative wound infections.

Patients and Methods: (126) swab specimens were cultured and isolates were identified by gram stain ,morphological and cultural characteristics of the colonies. The standard disc diffusion methods were done for determination of Antibiotics Resistance of all isolates as described by the Clinical Laboratory Standard Institute (CLSI) 16.

Results: A total of (126) patients presented with infected wounds were enrolled in this study. Out of (126) patients studied (43)patient (34\%) had no growth. While the others (83) patient $(66 \%)$ had positive bacterial isolate. From those with positive isolates (47) patient $(57 \%)$ were male and $36(43 \%)$ were female.The common bacterial isolate were E.coli (29\%) then Staphylococcus aureus and Acinetobacter spp.(19\%).Sensitivity testing show that E.coli had high resistance to Piperacillin, Aztreonam, Ticarcillin and Sulfamethoxazole. And Staphylococcus aureus had high resistance to Erythromycin and Sulfamethoxazole.

Conclusion: The common pathogen was E.coli and it was resistant to the commonly used antibiotics. While Staph.aureus was still sensitive to many antibiotics.

Keywords: Baqubah, Surgical wound, Antibiotics profile

Corresponding Author: Ammaralshummary72@yahoo.com

Received: $13^{\text {th }}$ June 2019

Accepted: $18^{\text {th }}$ June 2019

DOI:https://doi.org/10.26505/DJM.18014740613

${ }^{1,2,3,4}$ Baquba Teaching Hospital-Diyala Health Directorate-Health Ministry-Diyala-Iraq.

\section{Introduction}

In spite of the progress in surgery, surgical techniques and antibiotic prophylaxis[1,2,3]. postoperative infections remain the

commonest postoperative complications and one of the most frequently encountered nosocomial infections worldwide[4,5]. These 
Correlation of Medical Treatment for Wound Infection with Isolated Bacteria and Antibiotics Sensitivity

Profile in Baqubah Teaching Hospital

infections lead to increase morbidity with the attendant increase in cost of therapy[6].

The high incidence and prevalence of postoperative wound infections also result in increasing demand on the limited resources available to healthcare delivery eventually resulting in high degree of mortality[1,6]. The widespread use of antibiotics, together with the length of time over which they have been available have led to major problems of resistant organisms, contributing to morbidity and mortality.

Pathogens that infect surgical wounds can be part of the patient's normal flora (endogenous source) or acquired from the hospital environment or other infected patients (exogenous source).The skin bacteria comprise commensals, transients and pathogens. The transient organisms include S.aureus, the hospital acquired methicillinresistant forms (MRSA) and coliforms. Identification of a microbe that has been recovered from a clinical specimen is beneficial to the patient and assists in selection of chemotherapy[7].

\section{Patients and Methods}

\section{Identification of isolates}

The identification of bacterial isolates was done by standard biochemical tests on the isolates and these include;(1)gram stain (2) morphological and cultural characteristics of colonies on blood agar MacConkey agar, Brilliant Green Agar, Eosin Methylene Blue agar, and Mannitol Salt Agar, also hemolysis, production of oxidase, catalase and Coagulase tests were done to confirm pathogenic staphylococci. Further tests carried out for gram negative microorganisms included, nitrate reduction, motility test and hydrogen sulphide production, indole production, Methyl Red Voges Proskauer tests and other tests were done included citrate utilization, fermentation of sugar tests using maltose, mannitol, mannose, sorbitol, glucose, arabinose ,raffinose also Triple - Sugar Iron Agar tests was done .

\section{Antibiotic resistance testing}

The standard disc diffusion methods were done for determination of antibiotics resistance of all isolates as described by the Clinical Laboratory Standard Institute (CLSI). The test media was Isosensitest Agar supplemented with whole blood for aerobes and chocolate agar for anaerobes. Samples were collected prior to the antibiotics supplementations.

The antibiotic discs employed include: Ciprofloxacin(cip) $(5 \mu \mathrm{g})$,Amikacin(AK) $(30$ $\mu \mathrm{g})$,Erythromycin(E) $(15 \mu \mathrm{g})$, Tetracyclin(TE)

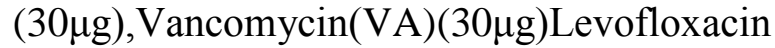
(LEV)

at $(\mu \mathrm{g} 5)$, Imipenem(IMP((10 $\mu \mathrm{g})$, Ampicillin(A M) $(25 \mu \mathrm{g}$,Ticarcillin(TIC)

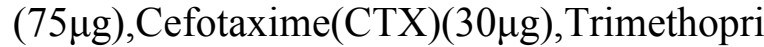
$\mathrm{m}(\mathrm{TIM})$

$(85 \mu \mathrm{g})$,Sulfamethoxazole(SXT) $(25 \mu \mathrm{g})$,Doxyc

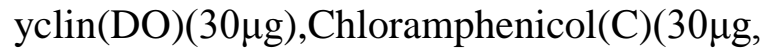
Piperacillin(PRL) (100 $\mu$ g), Ofloxacin(OFX) $(5 \mu \mathrm{g})$, Aztreonam(ATM) $(30 \mu \mathrm{g})$.

Measurement and interpretation for inhibition zones was done in accordance with manufacturers' instructions $\mathrm{AB}$, Biodisc; PDM Interpretative chart. Cultures for 
anaerobes and for fungal infections were not done in our hospital at the time of the study.

\section{Statistical analysis}

Data were collected on a specific questioners and an Excel Microsoft 2010 program used for data analysis.

\section{Results}

A total of (126) patients presented with infected wounds were enrolled in this study. (43)patient (34\%) had no growth. While the others (83) patient (66\%) had positive bacterial isolate. From those with positive isolates (47) patient $(57 \%)$ were male and (36) $(43 \%)$ were female.

The common bacterial isolate were E.coli $(29 \%)$ then Staphylococcus aureus and Acinetobacter spp.(19\%) as shown in Table(1).

Out of (126) patients studied

Table (1): Bacterial isolates recovered from surgical wound infections

\begin{tabular}{||l||c||}
\hline \multicolumn{1}{|c||}{ Organism } & NO.(\%) \\
\hline \hline Escherichia coli & $24(29 \%)$ \\
\hline \hline Staphylococcus aureus & $16(19 \%)$ \\
\hline \hline Acinetobacter spp. & $16(19 \%)$ \\
\hline \hline Pseudomonas aeruginosa & $11(13 \%)$ \\
\hline \hline Proteus mirabilis & $9(11 \%)$ \\
\hline \hline Streptococcus spp. & $6(8 \%)$ \\
\hline \hline Klebsiella pneumonia & $1(1 \%)$ \\
\hline \hline Total $(\%)$ & $83(100 \%)$ \\
\hline
\end{tabular}

These bacterial isolates were tested for sensitivity against many commonly used antibiotics and show variable resistance profile to many antibiotics as in E.coli which show high resistance to Piperacillin,
Aztreonam, Ticarcillin and Sulfamethoxazole. And Staphylococcus aureus which show high resistance to Erythromycin and Sulfamethoxazole. And as shown in Table(2). 
Correlation of Medical Treatment for Wound Infection with Isolated Bacteria and Antibiotics Sensitivity

Profile in Baqubah Teaching Hospital

Table (2): Sensitivity profile of bacterial isolates from Surgical Wound infections

\begin{tabular}{|c|c|c|c|c|c|c|c|c|c|c|c|c|c|c|c|c|c|c|}
\hline \multirow{2}{*}{$\begin{array}{l}\text { Organis } \\
\mathrm{m}\end{array}$} & \multirow{2}{*}{$\begin{array}{l}\text { No. } \\
\text { of } \\
\text { Isol } \\
\text { ates }\end{array}$} & \multicolumn{17}{|c|}{ N0. Of Isolates resistant (\%) } \\
\hline & & CIP & $\mathrm{AK}$ & E & $\mathrm{TE}$ & VA & LEV & $\begin{array}{l}\text { IP } \\
\text { M }\end{array}$ & $\mathrm{AM}$ & TIC & CTX & TIM & SXT & DO & $\mathrm{C}$ & PRL & $\begin{array}{c}\text { OF } \\
\text { X }\end{array}$ & $\begin{array}{l}\text { AT } \\
\text { M }\end{array}$ \\
\hline $\begin{array}{l}\text { Escheric } \\
\text { hia coli }\end{array}$ & 24 & $\begin{array}{l}5(21 \\
\%)\end{array}$ & $\begin{array}{l}5(21 \\
\%)\end{array}$ & ND & ND & $\begin{array}{l}2(8 \\
\%)\end{array}$ & $\begin{array}{l}4(17 \\
\%)\end{array}$ & 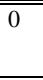 & $\begin{array}{l}11(4 \\
6 \%)\end{array}$ & $\begin{array}{l}13(5 \\
4 \%)\end{array}$ & $\begin{array}{l}10(4 \\
2 \%)\end{array}$ & $\begin{array}{l}6(25 \\
\%)\end{array}$ & $\begin{array}{l}12(5 \\
0 \%)\end{array}$ & $\begin{array}{l}4(17 \\
\%)\end{array}$ & $\begin{array}{l}2(8 \\
\%)\end{array}$ & $\begin{array}{l}18(7 \\
5 \%)\end{array}$ & $\begin{array}{l}8(33 \\
\%)\end{array}$ & $\begin{array}{l}14(5 \\
8 \%)\end{array}$ \\
\hline $\begin{array}{l}\text { Staphylo } \\
\text { coccus } \\
\text { aureus }\end{array}$ & 16 & $\begin{array}{l}\mathrm{N} \\
\mathrm{D}\end{array}$ & $\begin{array}{l}4(25 \\
\%)\end{array}$ & $\begin{array}{l}7(44 \\
\%)\end{array}$ & $\begin{array}{l}1(6 \\
\%)\end{array}$ & $\begin{array}{l}2(13 \\
\%)\end{array}$ & $\begin{array}{l}3(19 \\
\%)\end{array}$ & $\begin{array}{l}1(6 \\
\%)\end{array}$ & $\begin{array}{l}2(13 \\
\%)\end{array}$ & $\begin{array}{l}1(6 \\
\%)\end{array}$ & $\begin{array}{l}1(6 \\
\%)\end{array}$ & $\begin{array}{l}1(6 \\
\%)\end{array}$ & $\begin{array}{l}6(38 \\
\%)\end{array}$ & $\begin{array}{l}1(6 \\
\%)\end{array}$ & $\begin{array}{l}3(19 \\
\%)\end{array}$ & $\begin{array}{l}1(6 \\
\%)\end{array}$ & ND & ND \\
\hline $\begin{array}{l}\text { Acineto } \\
\text { bacter } \\
\text { spp. }\end{array}$ & 16 & ND & $\begin{array}{l}5(31 \\
\%)\end{array}$ & $\begin{array}{l}12(7 \\
5 \%)\end{array}$ & $\begin{array}{l}5(3 \\
1 \%)\end{array}$ & $\begin{array}{l}10(6 \\
3 \%)\end{array}$ & $\begin{array}{l}2(13 \\
\%)\end{array}$ & 0 & $\begin{array}{l}10(6 \\
3 \%)\end{array}$ & ND & $\begin{array}{l}8(50 \\
\%)\end{array}$ & $\begin{array}{l}10(6 \\
3 \%)\end{array}$ & $\begin{array}{l}14(8 \\
8 \%)\end{array}$ & $\begin{array}{l}3(19 \\
\%)\end{array}$ & ND & $\begin{array}{l}15(9 \\
4 \%)\end{array}$ & ND & ND \\
\hline $\begin{array}{l}\text { Pseudo } \\
\text { monas } \\
\text { aerugino } \\
\text { sa }\end{array}$ & 11 & $\begin{array}{l}2(18 \\
\%)\end{array}$ & $\begin{array}{l}1(9 \\
\%)\end{array}$ & $\begin{array}{l}1(9 \\
\%)\end{array}$ & $\begin{array}{l}1(9 \\
\%)\end{array}$ & ND & $\begin{array}{l}3(27 \\
\%)\end{array}$ & 0 & ND & $\begin{array}{l}4(36 \\
\%)\end{array}$ & ND & $\begin{array}{l}3(27 \\
\%)\end{array}$ & $\begin{array}{l}8(72 \\
\%)\end{array}$ & ND & $\begin{array}{l}4(36 \\
\%)\end{array}$ & $\begin{array}{l}3(27 \\
\%)\end{array}$ & $\begin{array}{l}1(9 \\
\%)\end{array}$ & $\begin{array}{l}1(9 \\
\%)\end{array}$ \\
\hline $\begin{array}{l}\text { Proteus } \\
\text { mirabilis }\end{array}$ & 9 & $\begin{array}{l}3(33 \\
\%)\end{array}$ & $\begin{array}{l}3(33 \\
\%)\end{array}$ & 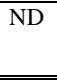 & \begin{tabular}{|l|} 
ND \\
\end{tabular} & $\begin{array}{l}\mathrm{ND} \\
\end{array}$ & $\begin{array}{l}1(11 \\
\%)\end{array}$ & 0 & $\begin{array}{l}6(67 \\
\%)\end{array}$ & $\begin{array}{l}5(56 \\
\%)\end{array}$ & $\begin{array}{l}7(78 \\
\%)\end{array}$ & \begin{tabular}{|l|} 
ND \\
\end{tabular} & $\begin{array}{l}7(78 \\
\%)\end{array}$ & $\begin{array}{l}8(89 \\
\%)\end{array}$ & $\begin{array}{l}8(89 \\
\%)\end{array}$ & $\begin{array}{l}5(56 \\
\%)\end{array}$ & $\begin{array}{l}4(44 \\
\%)\end{array}$ & $\begin{array}{l}4(44 \\
\%)\end{array}$ \\
\hline $\begin{array}{l}\text { Streptoc } \\
\text { occus } \\
\text { spp. }\end{array}$ & 6 & ND & ND & $\begin{array}{l}5(83 \\
\%)\end{array}$ & $\begin{array}{l}2(3 \\
3 \%)\end{array}$ & 0 & 0 & 0 & $\begin{array}{l}2(33 \\
\%)\end{array}$ & ND & $\begin{array}{l}2(33 \\
\%)\end{array}$ & ND & ND & ND & 0 & ND & 0 & ND \\
\hline $\begin{array}{l}\text { Klebsiel } \\
\text { la } \\
\text { pneumo } \\
\text { nia }\end{array}$ & 1 & $\begin{array}{l}1(10 \\
0 \%)\end{array}$ & ND & ND & ND & ND & 0 & 0 & 0 & 0 & 0 & $\begin{array}{l}1(10 \\
0 \%)\end{array}$ & ND & ND & ND & 0 & 0 & ND \\
\hline Total & 83 & $\begin{array}{l}11(1 \\
3 \%)\end{array}$ & $\begin{array}{l}18(2 \\
2 \%)\end{array}$ & $\begin{array}{l}25(3 \\
0 \%)\end{array}$ & $\begin{array}{l}9(1 \\
1 \%)\end{array}$ & $\begin{array}{l}14(1 \\
7 \%)\end{array}$ & $\begin{array}{l}13(1 \\
6 \%)\end{array}$ & $\begin{array}{l}1(1 \\
\%)\end{array}$ & $\begin{array}{l}31(3 \\
7 \%)\end{array}$ & $\begin{array}{l}23(2 \\
8 \%)\end{array}$ & $\begin{array}{l}28(3 \\
4 \%)\end{array}$ & $\begin{array}{l}21(2 \\
5 \%)\end{array}$ & $\begin{array}{l}47(5 \\
7 \%)\end{array}$ & $\begin{array}{l}16(1 \\
9 \%)\end{array}$ & $\begin{array}{l}17(2 \\
0 \%)\end{array}$ & $\begin{array}{l}42(5 \\
1 \%)\end{array}$ & $\begin{array}{l}13(1 \\
6 \%)\end{array}$ & $\begin{array}{l}19(2 \\
3 \%)\end{array}$ \\
\hline
\end{tabular}

*Ciprofloxacin(cip),Amikacin(AK),Erythromycin(E),Tetracyclin(TE),Vancomycin(V),Levofloxacin(LEV),Imipenem(IMP),Ampicillin(AM), T icarcillin(TIC),Cefotaxime(CTX), Trimethoprim(TIM),Sulfamethoxazole(SXT),Doxycyclin(DO),Chloramphenicol(C),Piperacillin(PRL),Oflox acin(OFX), Aztreonam(ATM).

The sensitivity profile of E.coli show high as shown in Figure(1). sensitivity to Imipenem and meropenem and

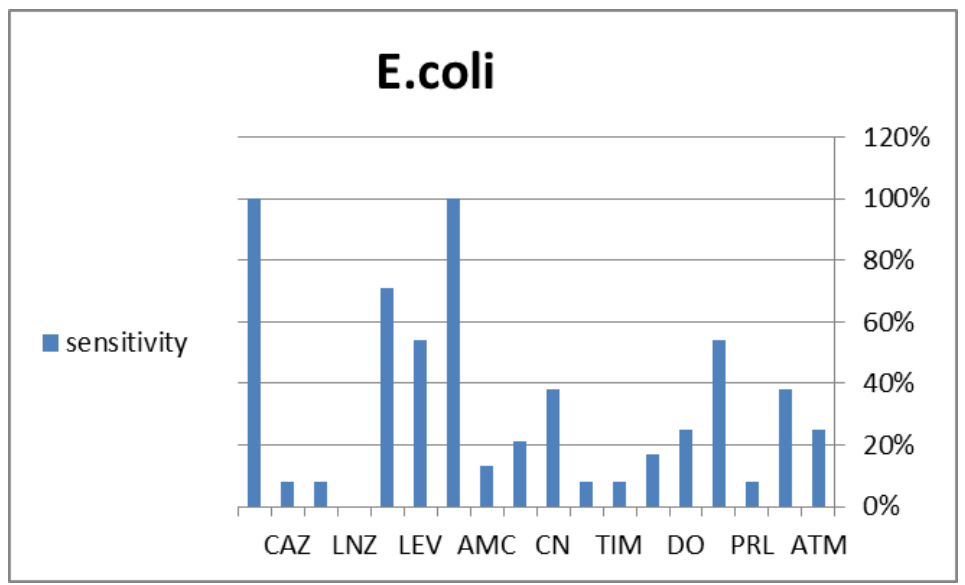

Figure(1):The antibiotic sensitivity of the E.coli isolates 
Correlation of Medical Treatment for Wound Infection with Isolated Bacteria and Antibiotics Sensitivity

Profile in Baqubah Teaching Hospital

While Staphylococcus Aureus show high

Vancomycin and as shown in Figure(2). sensitivity to Linezolid, Doxycycline and

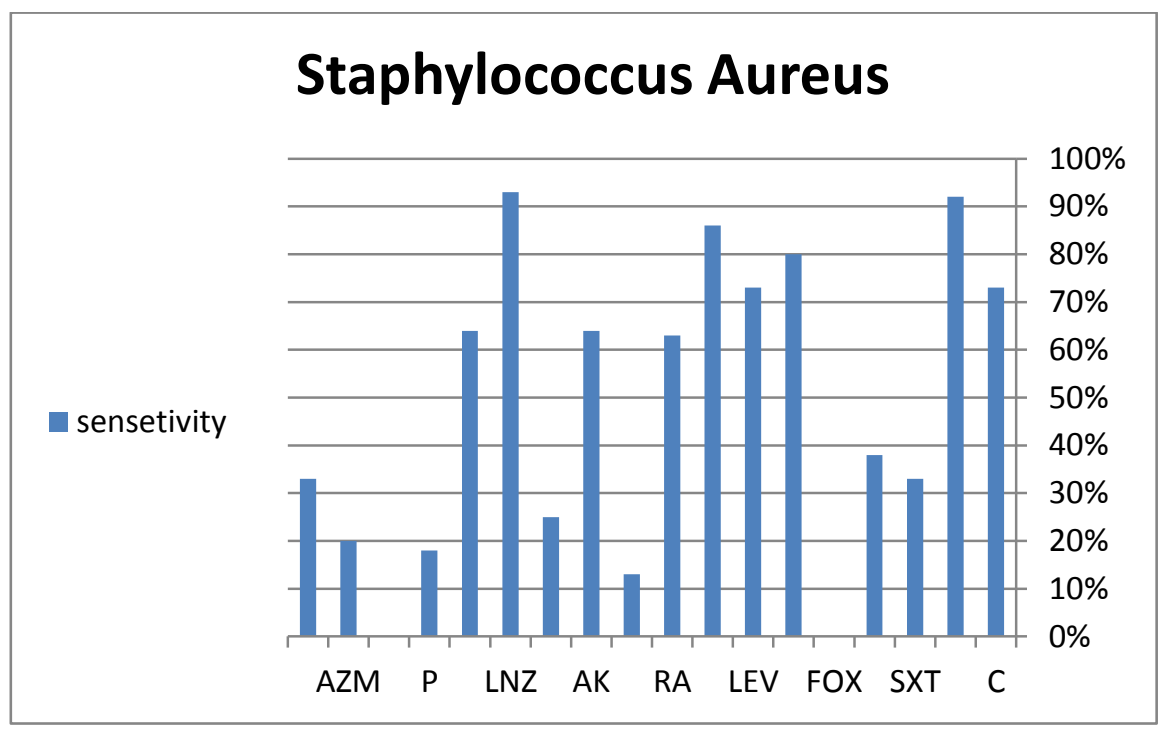

Figure(2):The antibiotic sensitivity of the Staphylococcus Aureus isolates

\section{Discussion}

In this study the commonest bacteria isolated were E.coli $(29 \%)$ followed by Staphylococcus Aureus (19\%)and Acinetobacter species (19\%) and this differ from the study done by Farrag and his colleagues in Egypt 2016[8], which show that the common organism was Klebsiella pneumonia (24\%) and also differ from studies done by Akinkunmi and his colleagues in Nigeria 2014[9], Anguzu and Olila in Uganda 2007[10], Shriyan and his colleagues in India 2010[11] and Giacometti and his colleagues in Italy 2000[12] which show the commonest organism were Staphylococcus aureus in $(18.2 \%, 45.1 \%$, $63 \%$ and $28.2 \%$ )respectively.

The E.coli isolates in this study were resistant to many commonly used antibiotics such as piperacillin(75\%), Aztreonam(58\%),
Ticarcillin(54\%), andSulfamethoxazole (50\%). And this differ from the findings of Akinkunmi and his colleagues in Nigeria 2014[9], which show that E.coli isolates were resistant to Pencillin V,pepracillin,Cephalothin,Cefadroxil and Trimethoprim in $100 \%$ of the isolates.And a study done by Anguzu and Olila in Uganda 2007[10], which show that E.coli isolates were resistant to Amoxacillin and Chloroamphinicol in $100 \%$, and Ampicillin $80 \%$ of the isolates. And the study done by Shriyan and his colleagues in India 2010[11]which show that E.coli were resistant to Cephalosporins in $40 \%$ of the isolates.

The E.coli isolates in this study were resistant to many commonly used antibiotics such

piperacillin 
Correlation of Medical Treatment for Wound Infection with Isolated Bacteria and Antibiotics Sensitivity

Profile in Baqubah Teaching Hospital

(75\%),Aztreonam(58\%), Ticarcillin(54\%), and Sulfamethoxazole (50\%).And this differ from the findings of Akinkunmi and his colleagues in Nigeria 2014[9], which show that E.coli isolates were resistant to PencillinV,pepracillin,Cephalothin,Cefadroxi 1 and Trimethoprim in 100\% of the isolates.And a study done by Anguzu and Olila in Uganda 2007[10], which show that E.coli isolates were resistant to Amoxacillin and Chloroamphinicol in $100 \%$, and Ampicillin $80 \%$ of the isolates. And the study done by Shriyan and his colleagues in India 2010[11],which show that E.coli were resistant to Cephalosporins in $40 \%$ of the isolates.

While Staphylococcus Aureus show good sensitivity profile to many antibiotics such as Linezolid(93\%),Doxycycline(92\%),Vancomy $\operatorname{cin}(85 \%)$,Imipenem(80\%),Levofloxacin(72\% ),Chloramphenicol(72\%), andAmikacin(63\%) .And this findings were differ from that reported by Akinkunmi and his colleagues in Nigeria 2014[9], which found that Staph.aureus were sensitive to Ciprofloxacin and ofloxacin in $100 \%$, and sensitive to Chloramphinicol 65\%,Fucidic acid 55\% and Tobramycin 55\%.And another study done by Anguzu and Olila in Uganda 2007[10], which show Staph.aureus sensitive to Gentamycin 87.5\%,Methicillin 75\% and Ciprofloxacin $68.7 \%$. And another study done by Shriyan and his colleagues in India 2010[11],which show that Staph.aureus were sensitive to Vancomycin100\%,Teicoplanin 100\%,Linzold $100 \%$,Clindamycin 100\%, Gentamycin $98.2 \%$ and Cephazolin $98.2 \%$. In this study $34 \%$ of cases they had no growth of organisms which most probably due to antibiotics used prior to surgery.

\section{Conclusions}

The common pathogen was E.coli and it was resistant to the commonly used antibiotics. While Staph.aureus was still sensitive to many antibiotics.

\section{Recommendation}

Future studies should be extended to include fungal cultures and cultures under anaerobic conditions to establish the presence of other organisms that require such environment for growth. A regular surveillance should be carried out to monitor the susceptibility of these pathogens and chose appropriate regimens both for prophylaxis and treatment of surgical wound infections.

Antibiotics misuse prior to surgery should be avoided as possible as we can to minimize antibiotics resistance.

\section{References}

[1]Bowler PG, Duerden BI, Armstrong DG. Wound Microbiology and Associated Approaches to wound management.Clinical Microbiology Review 2001; 14(2):244-269. [2]Nichols RL. Current Strategies for Prevention of Surgical Site Infections. Curr Infect Dis Rep 2004; 6(6):426-434.

[3]Surucuoglu S, Gazi H, Kurutepe S, Ozkutuk N, Ozbakkaloglu B. Bacteriology of surgical wound infections in a tertiary care hospital in Turkey. East Afr Med J 2005;82:331-336.

[4]Tesfahunegn Z, Asrat D, Woldeamanuel Y, Estifanos K. Bacteriology of surgical site 
Correlation of Medical Treatment for Wound Infection with Isolated Bacteria and Antibiotics Sensitivity

Profile in Baqubah Teaching Hospital

and catheter related urinary tract infections among patients admitted in Mekele Hospital,Mekele, Tigray, Ethiopia. Ethiopian Medical Journal 2009; 47:117-122.

[5]Ashby E, Haddad FS, O'Donnell E, Wilson AP. How will surgical site infection be measured to ensure "high quality care for all"? The Journal of Bone and Joint Surgery 2010; 92(9):1294-1299.

[6]Mangram AJ, Horan TC, Pearson ML, Silver LC,Jarvis WR. Guideline for prevention of surgical site infection,1999. Hospital Infection Control Practices Advisory Committee. Infection Control Hospital Epidemiology1999; 20(4):250-278. [7]Elmer W.K, Stephen D.A, William M.J, Paul C,Schreckenberger, Washingtone C, Winn Jr. Antimicrobial susceptibility testing in, Colour Atlas and text Book of Diagnostic microbiology 5th edition: 69-120.Raven Publisher, 227 East Washington Square, Philadelphia, 1997.

[8]Farrag HA, Hassan Abd El-Rehim, Mahmoud Hazaa M and Sobhy El- Sayed SA. Prevalence of Pathogenic Bacterial Isolates Infecting Wounds and their Antibiotic Sensitivity. Journal of Infectious Diseases and Treatment 2016; Vol. 2 No. 2: 15:1-7.

[9]Akinkunmi E.O, Adesunkanmi A, Lamikanra A. Pattern of pathogens from surgical wound infections in a Nigerian hospital and their antimicrobial susceptibility profiles. African Health Sciences 2014; Vol 14 Issue (4):802-809.

[10] Anguzu JR and Olila D. Drug sensitivity patterns of bacterial isolates from septic post- operative wounds in a regional referral hospital in Uganda. African Health Sciences 2007; Vol 7 No(3):148-154. [11]Shriyan A, Sheetal R and Nayak N. Aerobic Micro-Organisms In Post-Operative Wound Infections And Their Antimicrobial Susceptibility Patterns. Journal of Clinical and Diagnostic Research 2010 December;(3393 4):3392-3396. [12]Giacometti A, Cirioni O, Schimizzi AM, Delprete MS, Barchiesi F, D'errico MM, Petrelli E, and Scalise G. Epidemiology and Microbiology of Surgical Wound Infections.Journal of clinical microbiology Feb.2000;Vol.38,No.2:918-922. 